\title{
THE CONSTITUTIONAL FOUNDATION OF WAR CLAIMS FOR PROPERIY.
}

I. Some exceptions to the exclusive Right of Property.

1. Eminent Domain.

THE law of all nations has always recognised the right of the sovereign power to take private property from the owner, under certain conditions: Vattel, sect. 244; Grotius, bk. III., c. 20, s. VII.; Puffendorf, bk. VIII, ch. V., VII. This is called the right of eminent domain.

The conditions of its exercise are two in number, first, that the taking shall be for public use: 2 Kent's Com. 340 ; Grotius, $u b \imath$ supra; and secondly, that compensation shall be provided: 2 Kent's Com. 339; 1 Bl. Com. 139; Grotius, ubi supra; Puffendorf, ubi supra. The right of compensation, says STORY, "is founded in natural equity, and is laid down by jurists as a principle of universal law : Gonst., sect. 1790. The common law from the earliest days has upheld it. It is guaranteed in the Magna Charta, and again in the Petition of Right. So sacred did it seem to the fathers of our republic that it was included in the Bill of Rights adopted almost contemporaneously with our Constitution. The fifth article in the Bill of Rights provides that "private property shall not be taken for public use without just compensation."

Most of the states of the Union have affirmed the same principle in their constitutions, and even where no such written guarantee was given, the Supreme Court of Georgia, saying that " the sacredness of property ought not to be confided to the uncertain virtue of those who govern," held a law invalid which proposed to take the property of a private citizen for a public roadway, without any compensation: Parham v. Justices, 9 Ga. 348. Under this fundamental provision it has been held either that the compensation must be provided before the taking, or that the means of compensation must be made certain; but some states, believing that the right of private property ought to be still more secure, have expressly excluded this latter alternative: $1 \mathrm{Bl}$. Com. 139, note 17, by Cooley; Sedgwick on Constr. of Stat. and Const. Law, $2 \mathrm{~J}$ .ed., 468 . 
2. The right of necessity.

A second exception to the exclusive right of property is recognised by the law of nature and of nations (Puffend., bk. VII, c. V., VII.), an exception expressed by the common-law maxim, "necessitas inducit privilegium quoad jura privata": Broom's Legal Maxims 11. "If a man, who is assaulted and in danger of his life, run through the close of another without kecping in a footpath, an action of trespass does not lie, because the doing of this, it being necessary for the preservation of his life, is lawful :" 9 Bac. Abr. 480. Where a road is out of repair, a traveller may go upon private property; in time of fire, houses may be pulled down to prevent the spread of the fire; and the books give other instances "It is a right not susceptible of any precise definition, for the mode and manner and extent of its exereise, must depend upon the nature and degree of necessity that calls it into action, and this cannot be determined until the necessity is made to appear:" Hale v. Lawrence, 1 Zabr. (N. J.) 729.

Besides these instances of the invasion of the rights of property by private individuals, where necessity becomes a higher law than the property rights of others, many cases arise in which a public officer, acting on behalf of the government, has equal or greater privileges: Mitchell v. Harmony, 13 How. 134; 9 Bac. Abr. 483.

It is war, called by a learned moral writer, "an abrogation of the ten commandments," which to some extent abrogates the law too, and the necessity of the hour becomes supreme. A military officer, on a march with famished troops, has no time to have the price of provisions, stored near by, assessed by a jury. On a hasty march, with the enemy at hand, an army cannot stop to decide how much shall be paid and to whom, for property which the retreating army cannot take, and the enemy must not have. And public law has always decreed that in these cases the necessity makes the law; the individual is despoiled; the safety of the people demands it: Vattel, sect. 121; Puffendorf, bk. VIII., ch. V., VII.

It will be readily seen, that the right of a public officer to seize or destroy private property, under an inevitable necessity in war, resembles both the ordinary private right of necessity, and the right of eminent domain. It is like the first, in the fact that no compensation need be tendered, nor even the means of compensation be made certain. It is like the second, in that the seizure or 
destruction is by public agents directly for public purposes, as much so as where land is taken for a public building. And in this respect, it is unlike the first, for it is always difficult to tell for whose benefit the private right of necessity is exercised: American Print Works v. Lawrence, $1 \mathrm{Zabr} .257$. Sometimes it is for the adrantage of the individual exercising it, sometimes for a limited number of persons; nearly always, the element of public policy attends the right.

It is a mere corollary to add, that when property is thus taken in case of necessity, the officer who acts on behalf of the government is under no liability to the owner. No tort is committed; and he cannot be held on any contract, for he is a mere public agent acting openly and within his rightful authority. If the owner has any remedy, it must, then, be against the government. He has certainly suffered loss. Is he without remedy? If he has a remedy, on what principles does it rest? Where must he seek it? These are the questions now to be considered.

\section{Soits against the Government.}

Under the civil law, the sovereign is liable to suit like any private individual, whether the action be upon contract or in tort: Brown's Case, 6 Court of Claims 192. By the common law the government cannot be sued except by its own consent. In England the proceeding by petition of right was onlarged and extended by stat. 23 \& 24 Vict., and now is nearly as extensive as the civil-law proceeding against the sovereign: Brown's Case, supra. In the United States, the crying evil of the exemption of the government from suit, was remedied in part, in 1855 , by the passage of the act establishing the Court of Claims: 10 Stat. 612. Jurisdiction was given this court to "hear and determine all claims founded upon any law of Congress, or upon any regulation of an executive department, or upon any contract, express or implied, with the government of the United States."

By the Act of July 4th 1864, the remedy in the Court of Claims was taken away in all "claims against the United States growing out of the destruction or appropriation of, or damage to property by the army or navy, or any part of the army or navy engaged in the suppression of the rebellion, from the commencement to the close thereof :" 13 Stat. 381 . This limitation, being confined to the late rebellion, leaves the jurisdiction of this court unimpaired as to causes of action arising out of any other war. 
Rights which, after the formation of this court, are legally enforceable, existed before its formation; but, in the language of public law, only as "imperfect rights," or "moral claims :" Woolsey Int. Law, sect. 16. And this is the nature of all rights arising out of the destruction or appropriation of property in the late war by the Federal army or navy.

The obligation of such rights is like the obligation upon an individual of a contract, not in writing, within the Statute of Frauds. The overruling moral law, in either case, imposes an obligation upon the public or private conscience, although neither obligation can be enforced in any court. Where this moral obligation is upon the government, there may be also a provision of the supreme constitutional law recognising it; but if the legislature refuses to create a forum, the individual has no judicial remedy.

No action in tort is maintainable against the government in the Court of Claims : Langford v. United States, 101 U. S. 345.

\section{The Constitutional requirement of Compensation} for Property taken under necessity.

The fifth article of the amendments to the Constitution of the United States reads as follows: "No person shall be held to answer for a capital, or otherwise infamous crime, unless on a presentment or indictment of a grand jury, except in cases arising in the land or naval forces, or in the militia, when in actual service in time of war or public danger; nor shall any person be subject for the same offence to be twice put in jeopardy of life or limb; nor shall be compelled, in any criminal case to be a witness against himself, nor be deprived of life, liberty or property without due process of law; nor shall private property be taken for public use without just compensation."

It is said that the last clause of this article does not oblige the government to pay for property taken by a public agent, under an inevitable necessity in time of war; and that it applies solely to the right of eminent domain, exercised in time of peace.

A consideration of the reason and the authorities compels me to disagree with this view, and to believe that property taken in war, for the public benefit, is "property taken for public use," within the constitutional provision. It has been seen that unlike the rule in time of peace, the compensation in time of war need not be previously tendered, nor the means of compensation even be made 
certain; but this need not exclude the obligation of a future just compensation.

The question of payment may be complicated by the fact that the property is situated in the enemy's country; or is taken from a citizen of that country; or in a civil war, from a disloyal citizen: or by the other circumstances of the taking. Laying aside these complications, this discussion will be confined to the question, does the constitutional provision, requiring compensation for "private property taken for public use," include property taken in war under an inevitable necessity?

1. It is argued that the clause refers to the right of eminent domain, and not to the taking of private property under an inevitable necessity; that following the analogous privilege of individuals in overruling necessity, the government is under no obligation to reimburse the individual loser. The argument is founded on a distinction of mere words. The very point of resemblance between a taking of private property by the right of eminent domain in peace, and under a public necessity in war, is the vital and central point-that in both cases, the property is taken for public use. This is the reason, in the one case, why compensation must be made-it is equally forcible in the other. To say that private property, taken under a charter of a railroad corporation for the benefit of comparatively few travellers, is taken for public use, and to deny that term, when property is taken for the nation's highest necessities by a public officer, is to deny to the plainest words their clearest meaning. The necessity permits, it is true, the suspension of payment, but the taking creates an obligation to pay.

2. It is said, secondly, that this article and others in the Bill of Rights have no application whatever in time of war, and that the guarantees of civil rights in the Constitution are not binding except in time of peace.

It cannot be questioned that with the adoption of the Constitution, giving to Congress the power to declare war, and to the president the command and direction of the military forces, the international laws of war were also adopted, as a part of the Constitution, necessary to its preservation. Thus, in a district where the civil courts are closed, trials may be conducted by the military courts organized for such purposes under the laws of war: The Grapeshot, 9 Wall. 133; Leitensdorfer v. Webb, 20 How. 176. 
There is no question that when the necessities of war require it, a peaceful citizen may be deprived of his property, with no process of law other than the issuance of the command of an officer and an immediate seizure by a squad of armed soldiers. Our military cemeteries are a sad record of men deprived of life, without an indictment, without a trial by jury, without assistance of counsel, without witnesses on either side. Yet no one can contend that all these violations of the constitutional guarantees of the Bill of Bights are otherwise than lawful, because done in war, under a sanction of laws recognised in the Constitution as. suspending its provisions.

But how far does this suspension go? What bounds are to be set to it? The Supreme Court of the United States in the great case, Ex parte Milligan, 4 Wall. 127 (Davis, J.), speak as follows in regard to the operation of martial law. Their language equally applies to the present subject of discussion. "It follows that there are occasions when martial rule can be properly applied. If in foreign invasion, or civil war, the courts are actually closed, and it is impossible to administer criminal justice according to law, then, on the theatre of active military operations, where war really prevails, there is a necessity to furnish a substitute for the civil authority thus overthrown, to preserve the safety of the army and society; and as no power is left but the military, it is allowed to govern by martial rule until the laws can have their free course. As necessity creates the rule, so it limits its duration; for if this government is continued after the courts are reinstated, it is a gross usurpation of power."

The line here is distinctly drawn. Necessity causes the suspension of the constitutional guarantees, but when the necessity ceases, these provisions again resume their force. Necessity compels the taking of private property for public use without giving compensation at the time. The necessity extends no further. There is no such overruling necessity that the property shall not be paid. for, on demand to the proper authorities. With the taking of the property arises an implied contract on the part of the government to compensate the owner when opportunity offers, when the overruling necessity ceases. The laws and the necessities of war are in no conflict with this obligation.

"The Constitution of the United States," says Mr. Justice DAvis, in the case already referred to (Ex parte Milligan, supra), 
" is a law for rulers and people, equally in war and in peace, and covers with the shield of its protection all classes of men, at all times and under all circumstances. No doctrine involving more pernicious consequences was ever invented by the wit of man, than that any of its provisions can be suspended during any of the great exigencies of government. Such a doctrine leads directly to anarchy or despotism; but the theory of necessity on which it is based is false; for the government, within the Constitution, has all the powers granted to it which are necessary to preserve its existence."

3. A third objection is urged, that if the obligation of the government for losses in war were admitted, then the public treasury would become impoverished, and even exhausted. The principle of overruling necessity is stretched so that it may cover times of peace as well as times of war. We are told that a wide exception is to be judicially inserted in the Constitution upon very doubtful grounds of policy.

The argument from public policy is in this case purely political. When the words of a statute are doubtful, public policy may decide the undetermined scale; but otherwise, it has no place in a judicial or legal decision. A departure from the plain ways of legal interpretation and construction into these uncertain paths is to mistake the province of the judge: it is to make him a legislator. "Ita lex scripta est," can be the only judicial answer in such a case.

The federal legislature has passed upon the expediency of allowing a judicial decision upon claims against the United States arising out of the late civil war. In the midst of that great struggle, it took away the jurisdiction of the Court of Claims, as we have already seen, over claims for the destruction or appropriation of, or damage to property in that war. (July 4th 1864, 13 Stat. 381.) What may be, and may already have been, the effect of this aroidance of a legal obligation upon the morals and patriotism of the country, is not a subject to be considered in a purely legal discussion.

\section{Direct Judicial Adthorities.}

The authorities directly bearing upon the subject of compensation for property used or destroyed in war, under an inevitable necessity, are very few. There is but one systematic treatise on 
the subject, to my knowledge- a report to the House of Representatives, by the Hon. William Lawrence, on behalf of the Committee on War Claims, 43d Congress, Ist Session, March 1874, Rep. No. 262, in greater part republished in the $13 \mathrm{Am}$. Law Reg. (N. S.), pp. 265, 337, 401, and afterwards re-issued by authority of Congress, in permanent form. In his work on "War Powers under the Constitution," the Hon. William Whiting barely glances at the subject. Five decisions and five dicta are all the direct judicial expressions that reward a careful search in the American and English reports. The reason is clear. Our late civil war is the only recent war where the necessities have been so great and so pressing as to force a government frequently to take the property of its own citizens, without compensation at the time; and Congress, as we have seen, withdrew jurisdiction from the Court of Claims, as to that war.

Two decided cases and two dicta are cited to show that the government is not liable for property "taken for public use," in time of war. Rightly considered, I believe that only one furnishes authority for this view.

In the Saltpetre Case, 12 Rep. 12, it was considered justifiable, on the ground of overruling necessity in time of threatened war, for the servants of the Crown to go upon private land and dig and carry away saltpetre for use in making gunpowder. No question appears to have been raised as to compensation, but the decision seems to imply that none ought to be made. The only value of this case, at the present day, is to show what was then adjudged to be the law. As an authority, it is of no value whatever. The rule laid down by the Supreme Court of the United States, in Mitchell v. Harmony, 13 How. 134, is directly opposed to the idea of this case. "The danger must be immediate and impending, or the necessity urgent for the public service, such as will not admit of delay, and where the action of the civil authority would be too late in providing the means which the occasion calls for. "Extreme necessity alone," say the Supreme Court of Georgia, "can justify these cases and all others occupying the same ground:" Parham v. Justices, $9 \mathrm{Ga}$. 349. The rights of the government in republican America are not to be measured by the royal prerogative in the days of the Stuarts.

In the case of Governor \& Company of British Cast Plate Manu facturers v. Meredith (an action against a paving commissioner

Vox. 'XXIX.-30 
under an Act of Parliament, for damages from the raising of a roadway, 4 Term Rep. 794), Mr. Justice Buller says (p. 797): "There are many cases in which individuals sustain an injury, for which the law gives no action; for instance, pulling down houses or raising bulwarks for the preservation of the kingdom against the king's enemies. The civil-law writers, indeed, say that the individuals who suffer have a right to resort to the public for a satisfaction; but no one ever thought that the common law gave an action against the individual who pulled down the house, \&c. This is one of those cases to which the maxim applies, salus populi suprema lex. If the thing complained of were lawful at the time, no action can be sustained against the party doing the act." This does not deny an imperfect right, an equitable claim for compensation against the government where property is taken or destroyed for the public good. It merely denies that any action is given at common law, a position which no one has ever attempted to question.

A dictum in the early case of Parham v. Justices, $9 \mathrm{Ga} .348$, seems to admit the justice of claims for damages in war, but denies a right of suit against the sovereignty, which indeed did not exist at that time. "It is not to be doubted but that there are cases in which private property may be taken for a public use without the consent of the owner, and without compensation and without any provision of law for making compensation. These are cases of urgent public necessity, which no law has anticipated and which cannot await the action of the legislature. In such cases, the injured individual has no redress at law; those who seize his property are not trespassers, and there is no relief for him but by petition to the legislature. For example: the pulling down houses and raising bulwarks for the defence of the state against an enemy; seizing corn and other provisions for the sustenance of an army in time of war, or taking cotton-bags, as General Jackson did at New Orleans, to build ramparts against an invading foe." There is no denial here whatever of the existence of an obligation on the part of the government thus benefited-a duty-to recompense the individuals; no denial that the property taken under necessity is "taken for public use," within the constitutional principle, but a mere assertion of that which " is not to be doubted," that the necessity releases from the obligation of present payment and that the owner had no redress, at law, at that time. 
The last and the strongest judicial expression cited to show that no liability on the part of the government exists, in such cases, is the decision in the case of Respublica v. Sparhawk, 1 Dall. 383. During the Revolution, the city of Philadelphia was threatened. To prevent provisions from falling into the hands of the British troops, the Board of War ordered the removal of both public and private property to Chestnut Hill, a safer place. The enemy, however, took both Philadelphia and the supply depot at Chestnut Hill. Among the goods removed there and captured, were two hundred and twenty-seven barrels of flour, belonging to Sparhawk. He exhibited an account to the comptroller-general, for the value, under a statute providing this mode of settlement of claims, "for services rendered, moneys advanced, or articles furmished by order of the legislative or executive power." The decision of that officer was adverse and an appeal was taken (as provided by statute), to the Supreme Court of Pennsylvania. The decision of the comptroller-general was there affirmed on two grounds: first, that the claimint ought not to receive compensation upon the principles of law, and secondly, that under the statute just quoted, the court had no jurisdiction of the claim. After showing that the officers were not liable for the trespass, the court say (p. 388): "We are clearly of opinion that Congress might lawfully direct the removal of any articles that were necessary to the maintenance of the continental army, or useful to the enemy, and in danger of falling into their hands; for they were vested with the powers of peace and war, to which this was a natural and necessary incident: and having done it lawfully, there is nothing in the circumstances of the case which, we think, entitles the appellant to a compensation for the consequent loss." It must, however, be noticed that to decide secondly, that the court had no jurisdiction of the case, greatly lessens the weight of its opinion on the merits, reducing it towards the level of a mere dictum. This completes the examination of judicial expressions which may be cited to show that property appropriated or destroyed in war is not within the constitutional provision of compensation.

A brief reference to the recent case of Langford $\mathbf{v}$. The United States, 12 Court of Claims 338; 101 U. S. 341, may here be thought necessary. The facts shown are, that the American Board of Commissioners for Foreign Missions (who afterward assigned their title to the claimant) occupied land in Washington Territory, elaim- 
ing title thereto. They were forcibly dispossessed by the United States forces, under direction of the Secretaries of War and the Interior, and the lands and the buildings thereon were used as an Indian agency; the United States claiming to hold under a paramount title. . The Supreme Court rendered judgment for the United States, on the ground that the Court of Claims had no jurisdiction, saying (p. 342): "Conceding that the title, or even the right to the possession of the premises, was in claimant, it would seem that the facts above stated show that the act of the United States, in taking possession was an unequivocal tort, if the government can be capable of committing one, and that if the case mere between individuals every implication of a contract would be repelled." Then the court add (p. 343): "We are not called upon to decide that when the government, acting by the forms which are sufficient to bind it, recognises the fact that it is taking private property for public use, the compensation may not be recovered in the Court of Claims. On this point, we decide nothing." Where private property is taken in war, under an inevitable necessity, there is no tort and the government does not deny that it is private property. As to this, the case cited "decides nothing," and can have no bearing on the present discussion.

On the other side, favoring compensation, are three dicta and two direct decisions.

In the case of the Mayor, \&e., of New Fork v. Lord, 17 Wend. 291, NeLsoN, C. J., in delivering the opinion of the Supreme Court of New York, says: "If the public necessity in fact exists, the act is lawful. Thus, houses may be pulled down or bulwarks raised for the defence and preservation of the country, without subjecting the persons concerned to an action, the same as pulling down houses in time of fire; and yet these are common cases where the sufferers would be entitled to compensation from the national government within the constitutional principle."

In the Court of Errors of New York, Porter, Senator, says, (Russell v. The Mayor, \&c., of New York, 2 Denio 483): "I apprehend that the constitutional limitation was not designed for, and should not be extended to any such case," (that of pulling down houses to prevent the spread of fire); "but that the clause has reference only to cases where the property of an individual is taken for some public benefit or advantage. A vessel may, in time of war, be taken from the owner when the interest of the 
public dernands it; or it may be destroyed to prevent its falling into the hands of the enemy, and thereby increase its power of aggression or resistance; and the owner would be entitled upon this principle of the Constitution to be paid a just compensation.

Nothing could more clearly support the proposition advanced than these two dicta. They are found in cases belonging to the same series, growing out of the great fire in New York in the year 1835-cases involving immense sums of money and which were argued and considered with the greatest care.

The case of Mitchell v. Harmony, 13 How. 115, was an action by a trader (defendant in error), against a lieutenant colonel in the United States army. Harmony had made an extensive outlay of money and had gone into New Mexico intending to establish trade with the inhabitants. Mitchell compelled the trader, who had found a desirable location and wished to stop, to accompany the army on a farther expedition of four hundred miles, justifying his action by maintaining the illegality of Harmony's intentions and the necessity of the supplies to the army. The expedition ended disastrously and the property of Harmony fell into the enemy's hands. An action was brought against Mitchell in the Circuit Court for the Southern District of New York, and a verdict rendered for the plaintiff. The judgment was affirmed in the Supreme Conrt of the United States, and in delivering the opinion of the court, Mr. Chief Justice TANEX made use of the following language (p. 134): “There are without doubt occasions in which private property may lawfully be taken possession of and destroyed to prevent it from falling into the hands of the public enemy; and also, an officer, charged with a particular duty, may impress private property into public service or take it for public use. Uuquestionably in such cases, the government is bound to make full compensation to the owner; but the officer is not a trespassser."

Following the not uncertain voice of this court, as expressed by this great jurist, the Court of Claims in three successive cases, the only ones involving this principle ever before that court, have rendered judgment for the claimants. These are the cases of Grant $\nabla$. United States, 1 Court of Claims 41; Wiggins $\nabla$. United States, 3 Id. 412, and Campbell v. United States, 8 Id. 240. Many other cases would undoubtedly have arisen had not Congress, shortly after the first decision was rendered, as we have seen, 
withdrawn jurisdiction from the court in all such cases arising out of our late war.

The case of Grant v. United States, supra, was an action brought in 1863. William S. Grant was an army contractor, owning large mills and storehouses at Tucson, Arizona, in which was stored property belonging to himself and to the government. In JulJ 1861, the Texan rebel forces advanced in so large numbers that the United States army officers deemed it necessary to withdraw. Before leaving, the mills and all the stores of Grant were set on fire and destroyed to prevent their falling into the hands of the enemy. The necessity for the act was proved in the Court of Claims and judgment was given for the claimant for the value of all his property so destroyed. The court say (p. 50): "We hold, in this case, that the property was destroyed by the rightful order of the commanding officer, and upon an urgent and pressing necessity, and to prevent it from falling into the hands of the public enemy, and those hostile to the United States: that it was a taking for public use; and that the government is bound under the Constitution to make just compensation to the owner. The legal duty to make compensation raises an implied promise to do so; and here is found the jurisdiction of this court to entertain this proceeding."

The case of Wiggins v. Wnited States, supra, arose out of the bombardment of Greytown or San Juan, in Central America in 1854. The robbers and cut-throats who made this town their home constantly maltreated citizens of the United States who debarked there on their way to California, and finally assaulted a United States consul and a minister to one of the South American Republics. Reparation was demanded from the authorities by our government and refused. The ship of war Cyane was then sent there, with orders to ask again for reparation, and, if none was given, to open on the town. No satisfaction was received and the town was thereupon razed to the ground. Across the bay were stores belonging to a Boston company and a quantity of gunpowder belonging to Wiggins and others (assignees in bankruptcy), citizens of the United States. Fearing that the inhabitants would seize the powder and with it destroy the other stores, the naval commander sunk it in the sea. The President subsequently ratified the act. Wiggins and the other owners of the powder brought suit against the United States in the Court of Claims, which held 
the government liable for the value of the powder. CASEY, C. J., delivered the opinion, saying (p. 422): "We do not see how this case can be distinguished in principle from Grant $\mathrm{v}$. United States, supra. $* * * *$ Judge WILsor reviews at length the grounds of the claim, and the authorities bearing upon the subject, and shows most clearly and conclusively that, whether the property be taken and appropriated by right of $\epsilon$ minent domain, or destroyed to prevent other or greater injury to the public, the party is entitled to compensation; that this results as well from the principles of natural justice and equity as from the constitutional injunction to make compensation for private possessions devoted to public ends. We are entirely satisfied with the grounds there assumed, so far as they are applicable to the facts of this case, and can add nothing to the cogency or conclusiveness of the reasoning."

Campbell's Case, supra, is similar to the two preceding cases. The hull of a steamboat belonging to the petitioner was seized in October 1861, by order of General Grant, and carried to Cairo, to prevent its use by the Confederate forces, and was, in consequence, lost to the owner. A special act (16 Stat. 668), referred the case to the Court of Claims, which following its former decisions, rendered judgment for the claimant. No appeal was taken from this decision, nor do the questions of law appear to have been strongly disputed, the contest being merely as to the facts.

This completes the examination of the direct judicial authorities bearing on the subject of discussion.

From the authorities cited and from the reason of the case, two propositions can, I think, be considered established.

1. Property taken by proper authority under an inevitable necessity in war is within the constitutional provision requiring compensation.

2. Under the Court of Claims Act owners of such property have a legally enforceable right against the United States

William B. King.

Washington, D. C. 